\title{
PELATIHAN TEKNIS PEMBUATAN KOMPOS JERAMI PADI DI DESA BANJARREJO KECAMATAN BATANGHARI KABUPATEN LAMPUNG TIMUR
}

\section{(Technical Training Composting Of Rice Straw In Banjarejo Village, Batanghari District, East Lampung Regency)}

\author{
Dulbari $^{1^{*}}$, Yuriansyah ${ }^{1}$, Zainal Mutaqin ${ }^{1}$, Lisa $_{\text {Erfa }}{ }^{2}$, I Gde Darmaputra $^{3}$ \\ ${ }^{1}$ Program Studi Produksi Tanaman Pangan, Rajabasa Bandar Lampung \\ ${ }^{2}$ Program Studi Hortikultura, \\ ${ }^{3}$ Program Studi Teknik Survey dan Lingkungan, \\ Politeknik Negeri Lampung, \\ Jl. Soekarno Hatta No 10 Rajabasa Bandar Lampung
}

Email: dulbari23@yahoo.co.id

\begin{abstract}
The level of fertility of paddy fields in Banjarrejo was decreasing, this is indicated by low rice productivity, fertilization response was leveling of, topsoil were shallow, and rice easy lodged. Fertility degradation of paddy fields occurs continuously. Factors that encourage the ongoing process of soil fertility degradation is concept application of High External Input Agriculture (HEIA) on the cultivation of crops, especially rice.

Rice straw can be used as an alternative to increase soil fertility and maintain the health of paddy field. Straw is the main product of rice cultivation in the form of organic fertilizer because its potential reaches $1.5 x$ grain yield. However, the potential that is available cheaply and easily and Lack of information and knowledge about straw causes many farmers not to utilize straw to the fullest. Straw is still regarded as an obstacle in tillage, where the nest mice, disease sources, and sources of dirt that must be cleaned. Many farmers actually burn the its after harvesting, or get rid of it elsewhere because it is considered disturbing. Farmers have not used it to be composted because many still do not have the skills to make it.

State Polytechnic of Lampung has the role and responsibility to transfer technology that is beneficial to society especially in the case of making straw compost through program of Community Service. Technical Training Composting of Rice Straw was conduct in Banjarrejo Village, Batanghari District, East Lampung Regency in April-September 2013. The use of straw compost in paddy fields can increase rice production while maintaining sustainable soil health.
\end{abstract}

Keywords: Soil fertility, Straw compost, rice production

\section{Abstrak}

Tingkat kesuburan lahan sawah di Desa Banjarrejo semakin menurun, hal ini ditandai dengan produktivitas padi yang rendah, respon terhadap pemupukan melandai, lapisan bajak semakin dangkal, dan tanaman padi mudah rebah. Degradasi kesuburan lahan sawah terjadi secara terus menerus. Faktor yang mendorong terjadinya proses degradasi kesuburan lahan secara berkelanjutan adalah penerapan konsep High External Input Agriculture (HEIA) pada budidaya tanaman khususnya padi sawah. 
Jerami padi dapat dijadikan alternatif untuk meningkatkan kesuburan lahan dan menjaga kelestarian kesehatan lahan. Jerami merupakan produk utama bertanam padi sawah dalam bentuk pupuk organik karena potensinya mencapai $1,5 \mathrm{x}$ hasil gabah. Namun potensi yang tersedia secara murah dan mudah serta multi manfaat ini belum banyak dimanfaatkan oleh petani padi sawah, termasuk petani yang ada di Desa Banjarrejo. Kurangnya informasi dan pengetahuan tentang jerami menyebabkan banyak petani belum memanfaatkan jerami secara maksimal. Jerami masih dianggap sebagai bahan penghambat dalam pengolahan tanah, tempat bersarangnya tikus, sumber penyakit, dan sumber kotoran yang harus dibersihkan. Banyak petani yang justru membakar jerami setelah panen, atau menyingkirkannya ke tempat lain karena dianggap mengganggu. Petani belum memanfaatkannya menjadi kompos karena masih banyak yang belum mempunyai keterampilan untuk membuatnya.

Politeknik Negeri Lampung mempunyai peran dan tanggungjawab untuk mentransfer teknologi yang bermanfaat bagi masyarakat khususnya dalam hal pembuatan kompos jerami melalui program Pengabdian Kepada Masyarakat. Kegiatan Pelatihan Teknis Pembuatan Kompos Jerami dilaksanakan di Desa Banjarrejo Kecamatan Batanghari Kabupaten Lampung Timur pada April-September 2013. Penggunaan kompos jerami pada lahan sawah dapat meningkatkan produksi padi sekaligus menjaga kelestarian lahan secara berkelanjutan.

Kata Kunci : Kesuburan lahan, kompos Jerami, produksi padi

PENDAHULUAN Analisis Situasi

Desa Banjarrejo secara administratif masuk ke dalam wilayah Kecamatan Batanghari Kabupaten Lampung Timur, terdiri dari $27 \mathrm{RT}$ dan $8 \mathrm{RW}$. Luas Desa Banjarrejo 425,04 hektar dengan batas desa sebagai berikut : sebelah Utara bebatasan langsung dengan Desa Yosodadi, sebelah Selatan dengan Desa Rejo Agung dan Sumberrejo, sebelah Barat dengan Desa Tejo Agung dan Iring Mulyo, dan sebelah Timur dengan berbatasan dengan Desa Bumiharjo dan Adirejo. Secara geografis Desa Banjarrejo berada pada kisaran ketinggian 60- $73 \mathrm{~m} \mathrm{dpl}$, dengan intensitas curah hujan $685 \mathrm{~mm} / \mathrm{tahun}$, dengan suhu rata-rata harian berkisar $23^{\circ} \mathrm{C}-24^{\circ} \mathrm{C}$. Penduduk Desa Banjarrejo berjumlah 6.638 jiwa terdiri dari 3.368 laki-laki dan 3.270 perempuan. Sekitar 2.652 orang bekerja sebagai petani dan buruh tani. Walaupun sebagian besar warganya berusaha pada bidang pertanian, namun produktivitas padi sawah di Desa Banjarrejo masih rendah $( \pm 5$ ton ha ${ }^{-1}$ (Monografi Desa, 2010)

Salah satu penyebab rendahnya produktivitas padi tersebut adalah kondisi lahan sawah yang sakit dan semakin kritis akibat terjadinya degradasi kesuburan lahan. Degradasi kesuburan lahan sawah terjadi secara terus menerus, hal ini disebabkan oleh pola produksi yang menggunakan konsep HEIA (High External Input Agriculture). Usaha budidaya padi sawah yang bertumpu pada penggunaan bahan anorganik dan input eksternal. Penurunan kandungan bahan organik tanah, terjadi karena pengelolaan intensif, penanaman padi intensif hingga 2-3 kali setahun, mengandalkan tambahan hara dari bahan anorganik, begitu juga dengan pengelolaan Organisme Pengganggu Tanamannya (OPT) tergantung pada pestisida sintetik. Penggunaan pupuk anorganik yang intensif ini, walaupun mampu meningkatkan produksi padi dengan signifikan, ternyata juga memberikan dampak yang signifikan terhadap degradasi kesehatan dan kualitas 
tanah (Soil health and soil quality) (Simarmata, 2008; Turmuktini dan Simarmata, 2010).

Saat ini telah banyak dilakukan usaha budidaya tanaman padi yang menitikberatkan pada teknologi pengurangan penggunaan pupuk anorganik (Urea, SP36, dan $\mathrm{KCl}$ ) dengan harapan dapat mengurangi laju kerusakan lahan sekaligus mengurangi biaya produksi. Anjuran penggunaan teknologi efisiensi pupuk NPK tersebut masih perlu dilakukan pengkajian agar memberikan hasil yang optimal pada tingkat pelaksanaan di lapangan. Penurunan efisiensi penggunaan pupuk berkaitan erat dengan faktor tanah yang telah mengalami kemunduran kesehatan baik secara biologi maupun kimia akibat pengelolaan tanah yng kurang tepat.

Peningkatan mutu intensifikasi dengan menambah takaran dan jenis pupuk ternyata tidak mampun menghilangkan gejala kejenuhan produksi karena tanah yang digunakan sebagai media tumbuh telah kehilangan daya sanggahnya akibat penurunan kadar bahan organik. Hal ini banyak terjadi pada lahan sawah maupun lahan kering yang diusahakan secara intensif dan pengelolaannya tidak tepat. Pada saat panen padi jerami sisa panen banyak yang tidak dimanfaatkan bahkan dibuang/disingkirkan, padahal jerami merupakan salah satu sum ber bahan organic tanah (Rauf, 2007).

Sekitar $70 \%$ lahan lahan sawah di Indonesia mempunyai kandungan COrganik yang rendah $(<2 \%)$ (Simarmata dan Joy, 2011), hal ini juga menguatkan oleh penelitian yang dilakukan oleh Rauf (2007) terhadap lahan sawah di beberapa wilayah Sumatera Utara yang menemukan data bahwa kandungan C-Organikpada lahan tersebut berkisar 0,79\%. Dulbari (2012) yang melakukan analisis tanah di Desa Banjarrejo Kecamatan Batanghari Kabupaten Lampung Timur juga menemukan data bahwa kandungan COrganik pada lahan sawah di daerah tersebut hanya $0,89 \%$. Lahan dengan kandungan bahan organic $<1,5 \%$ termasuk dalam kategori lahan yang mengalami sakit berat (degradasi berat), setidaknya terdapat sekitar 5 juta hektar lahan dengan kondisi seperti ini di Indonesia (Simarmata dan Joy, 2011). Hal ini ditandai dengan melandainya respon terhadap pemupukan, peningkatan serangan organisme penggangu tanaman (OPT), lapisan bajak semakin dangkal, dan tanaman padi mudah rebah. Berdasarkan data-data tersebut sudah sangat mendesak untuk dilakukan upaya penambahan bahan organik ke dalam lahan sawah.

Pemanfaatan jerami setelah panen dapat dijadikan sebagai alternatif yang mudah dan murah bagi petani untuk menjaga kelestarian kesehatan dan kesuburan lahan sawahnya. Pemberian jerami pada lahan - lahan sawah di pulau Jawa telah terbukti mampu menggantikan keberadaan pupuk $\mathrm{K}$ dari sumber anorganik. Hal ini sejalan dengan arah pengembangan pertanian berkelanjutan dimasa yang akan datang, dengan masukan bahan kimia rendah (low chemical input) (Harjowigeno, 1995). Jerami sebenarnya merupakan produk utama bertanam padi sawah dalam bentuk pupuk organic karena potensinya mencapai 1,5 x hasil gabah. Hannya saja potensi melimpah yang dapat tersedia secara murah dan mudah serta multi manfaat ini belum banyak dimanfaatkan oleh petani padi sawah, termasuk petani yang ada di Desa Banjarrejo.

Kurangnya informasi dan pengetahuan tentang jerami menyebabkan banyak petani yang masih beranggapan bahwa jerami padi merupakan bahan penghambat dalam pengolahan tanah, tempat bersarangnya tikus, sumber penyakit, dan sumber kotoran yang harus dibersihkan. Banyak petani di Desa Banjarrejo yang justru membakar jerami setelah panen, atau 
menyingkirkannya ke tempat lain karena dianggap mengganggu. Petani belum memanfaatkannya menjadi kompos karena mereka belum memunyai keterampilan untuk melakukannya.

Politeknik Negeri Lampung mempunyai peran dan tanggungjawab dalam mentransfer teknologi yang bermanfaat bagi masyarakat khususnya dalam hal pembuatan kompos jerami, agar masyarakat mampun memanfaatkan jerami secara mandiri dan dapat menjadi bagian yang tidak terpisahkan dalam upaya menjaga keseimbangan agroekosistem lahan sawah. Dengan adanya upaya pemulihan kesehatan lahan sawah diharapkan produktivitas padinya meningkat dan kesejahteraan hidup petani juga meningkat. Untuk itu kegiatan pengabdian Bimbingan Teknis Pembuatan Kompos Jerami di Desa Banjarrejo Kecamatan Batanghari perlu dilakukan.

\section{Identifikasi dan Perumusan Masalah}

Sebagian besar masyarakat di Desa Banjarrejo Kecamatan Batanghari mengandalkan usaha di sektor pertanian untuk memenuhi kebutuhan diri dan keluarganya. Padi sawah adalah tanaman utama yang diusahakan, namun sayang komoditas ini belum mampu nmeningkatkan taraf hidup sebagian petani karena tingkat produktivitasnya yang masih rendah. Salah satu penyebab rendahnya produktivitas lahan padi adalah akibat menurunnnya tingkat kesehatan dan kesuburan lahan, hal ini dicirikan oleh rendahnya kandungan C-Organik (0,89\%) (Hasil analisis tanah lahan sawah Desa Banjarrejo Kecamatan Batanghari 2012 :
Dulbari, 2012). Dalam perannya menjaga kelestarian kesehatan dan kesuburan lahan sawahnya, Kelompok Tani Eko Budi Desa Banjarrejo diidentifikasi mempunyai permasalahan sebagai berikut:

a. Kurangnya pengetahuan dan informasi tentang jerami yang banyak tersedia di lahan yang dapat dipergunakan sebagai sumber bahan organik untuk menjaga kesehatan dan kesuburan lahan.

b. Petani lebih suka membakar jerami setelah panen karena alasan mengganggu pada saat akan melakukan pengolahan tanah.

c. Petani lebih suka melihat lahan sawahnya bersih dari jerami atau sisasisa tanaman, sehingga jerami dibuang atau disingkirkan dari lahan.

d. Petani belum mempunyai keterampilan untuk mengolah jerami menjadi kompos sebagai sumber bahan organik.

Dengan teridentifikasinya permasalahan yang dihadapi oleh petani pada kelompok tani Ekobudi 1 dan 2 di Desa Banjarrejo Kecamatan Batanghari melalui Ketua kelompoknya menyatakan kesediaanya untuk bekerjasama dan mendukung kegiatan pengabdian Pelatihan Teknis Pembuatan Kompos Jerami Padi di Desa Banjarrejo Kecamatan Batanghari. Anggota kelompok tani siap untuk diberikan materi penyuluhan dan sosialisasi tentang manfaat jerami bagi usaha pemulihan kesehata lahan sawah, serta sangat berharap untuk diberikan bingan teknis pembuatan kompos jerami dan cara aplikasinya oleh Tim Pengabdian Kepada Masyarakat Politeknik Negeri Lampung tahun 2013. Kerangka pemecahan masalah disajikan pada Tabel 1. 
Tabael 1 Rumusan kerangka pemecahan masalah

\begin{tabular}{clll}
\hline No & \multicolumn{1}{c}{ Kondisi saat ini } & \multicolumn{1}{c}{ Perlakuan } & \multicolumn{1}{c}{ Kondisi yang diharapkan } \\
\hline & $\begin{array}{l}\text { Petani kurang } \\
\text { pengetahuan dan } \\
\text { informasi tentang manfaat } \\
\text { jerami }\end{array}$ & $\begin{array}{l}\text { Penyuluhan, sosialisasi, } \\
\text { ceramah, dan diskusi }\end{array}$ & $\begin{array}{l}\text { memanfaran untuk } \\
\text { usaha menjaga kesehatan dan } \\
\text { kesuburan lahan sawah }\end{array}$ \\
\hline 2 & $\begin{array}{l}\text { Petani suka membakar } \\
\text { jerami }\end{array}$ & $\begin{array}{l}\text { Penyuluhan, sosialisasi, } \\
\text { ceramah, dan diskusi }\end{array}$ & $\begin{array}{l}\text { Petani tidak lagi membakar } \\
\text { jerami setelah panen }\end{array}$ \\
\hline 3 & $\begin{array}{l}\text { Petani suka membuang } \\
\text { jerami dari lahan sawah }\end{array}$ & $\begin{array}{l}\text { Penyuluhan, sosialisasi, } \\
\text { ceramah, dan diskusi }\end{array}$ & $\begin{array}{l}\text { Petani tidak lagi membuang } \\
\text { jerami di lahannya }\end{array}$ \\
\hline 4 & $\begin{array}{l}\text { Petani belum mempunyai } \\
\text { keterampilan dalam } \\
\text { membuat kompos jerami }\end{array}$ & $\begin{array}{l}\text { Ceramah, pelatihan teknis } \\
\text { diskusi, dan monitoring }\end{array}$ & $\begin{array}{l}\text { Petani mampu membuat } \\
\text { kompos jerami secara } \\
\text { sekaligus memanfaatkannya }\end{array}$ \\
\hline
\end{tabular}

\section{Tujuan Kegiatan}

a. Memberikan pengetahuan dan informasi kepada petani tentang manfaat jerami bagi peningkatan kesehatan dan kesuburan lahan sawah sehingga petani tidak lagi membuang dan membakar jerami yang ada di lahan sawah

b. Memberikan keterampilan pembuatan kompos jerami dan cara pemanfaatnnya kepada petani agar menjadi bagian yang tidak terpisahkan dalam usaha menjaga kelestarian kesehatan dan kesuburan lahan sawah.

c. Meningkatkan kesehatan dan kesuburan lahan sawah secara berkelanjutan sehingga proses degradasi lahan sawah dapat ditekan.

Dengan menerapkan cara bercocok tanam padi yang memperhatikan kelestarian lingkungan melalui pemanfaatan kompos jerami, maka produktivitas padi akan meningkat selanjutnya kesejahteraan petani khusunya anggota kelompok tani Eko Budi Desa Banjarrejo Kecamatan Batanghari juga meningkat.

\section{METODE PELAKSANAAN}

\section{Tempat dan Waktu Pelaksanaan Kegiatan}

Kegiatan pengabdian Pelatihan Teknis Pembuatan Kompos Jerami dilaksanakan di Desa Banjarrejo Kecamatan Batanghari Kabupaten Lampung Timur, dimulai dari bulan April sampai September 2013. Tindak lanjut dari kegiatan ini akan terus dilakukan monitoring dan pembinaan walaupun pelaksanaan kegiatan pengabdian sudah berakhir.

Metode Pelaksanaan
Kegiatan pengabdian kepada
masyarakat ini dilaksanakan dengan
melakukan kunjungan secara langsung ke
kelompok tani dan lahan garapannya di Desa
Banjarrejo Kecamatan Batanghari. Tim
pengabdian dari Politeknik Negeri Lampung
selanjutnya akan memberikan materi
penyuluhan dan sosialisasi seputar jerami
padi dan manfaatnya bagi usaha pemulihan
kesehatan lahan dan kesuburan lahan sawah.
Tahap selanjutnya adalah melakukan
pelatihan teknis pembuatan kompos jerami
dan cara aplikasinya di lapangan.
Tahap lebih rinci dari kegiatan
pengabdian yang dilaksanakan selama satu
musim tanam ini adalah sebagai berikut:
a. Kegiatan penyuluhan dan sosialisasi
tentang jerami padi dan manfaatnya bagi
usaha pemulihan kesehatan dan
kesuburan lahan sawah berkelanjutan.
Materi yang diberikan meliputi : potensi


jerami sebagai bahan pupuk organik di lahan sawah, kandungan bahan organik kompos jerami, manfaat kompos jerami terhadap perbaikan sifat fisik, kimia, dan biologi lahan sawah.

b. Kegiatan pelatihan teknis pembuatan kompos jerami dan cara aplikasinya di lapangan. Petani diberikan pelatihan secara langsung cara membuat kompos jerami, baik yang dilakukan secara langsung di lahan maupun cara pengomposan yang dilakukan secara terpusat. Materi pelatihan mulai dari bagaimana mempersiapkan bahan baku kompos jerami, berapa kebutuhan jerami yang diperlukan untuk masing-masing lahan, jenis dekomposer dan dosis ysng digunakan, cara menyusun kompos jerami pada bedengan pengemposan, penyiraman dan pemeliharaan yang harus dilakukan serta cara aplikasi kompos jerami dilapangan.

c. Melakukan monitoring selama pelaksanaan kegiatan dan setelah kegiatan dilaksanakan dengan harapan ada tindak lanjut penerapan teknologi khususnya pemanfaatan kompos jerami untuk usaha pemulihan kesehatan dan sesuburan lahan sawah yang ditransfer dari Tim Pengabdian Politeknik Negeri Lampung kepada kelompok tani dan masyarakat luas.

Metode pelaksanaan kegiatan pengabdian Pelatihan Teknis Pembuatan Kompos Jerami Padi di Desa Banjarrejo Kecamatan Batanghari Kabupaten Lampung Timur secara sederhana dapat dilihat pada skema Gambar 3 dibawah ini

\section{Evaluasi Kegiatan Pengabdian}

Untuk melihat sejauh mana tingkat keberhasilan kegiatan pengabdian Pelatihan Teknis Pembuatan Kompos Jerami Padi di Desa Banjarrejo Kecamatan Batanghari, dilakukan kegiatan evaluasi dan monitoring melalui beberapa tahapan yaitu : evaluasi tahap awal, evaluasi selama proses, evaluasi hasil, dan evaluasi akhir. Evaluasi awal dilakukan sebelum pelaksanaan kegiatan yang terdiri dari : a. Melakukan kunjungan sekaligus pengamatan (observasi) langsung kondisi lahan sawah petani anggota kelompok tani Eko Budi. b. Melakukan diskusi dengan petani seputar cara mereka selama ini melakukan penanganan terhadap jerami setelah panen. c. Menggali informasi dari data sekunder berupa monografi desa dan hasil penelitian terkait. Dari evaluasi awal dapat disimpulkan bahwa pengetahuan petani Eko Budi terhadap manfaat jerami padi sebagai sumber bahan organik yang dapat memperbaikai kesehatan dan kesuburan lahan sawah masih kurang. Petani belum mempunyai keterampilan yang cukup untuk mengolah jerami menjadi kompos. Berdasarkan evaluasi ini kemudian disusun materi yang akan diberikan dalam kegitan pengabdian ini.

Evaluasi proses dilakukan pada setiap tahapan proses dengan melakukan memberi pertanyaan seputar materi yang disampaikan. Bila ada peserta yang belum jelas dilakukan penjelasan ulang.

Evaluasi hasil dilakukan pada waktu seluruh materi penyuluhan dan sosialisasi seputar kompos jerami sudah diaikan, pelatihan teknis pembuatan kompos jerami padi dan cara aplikasinya sudah silaksanakan. Pada tahap ini tingkat keberhasilan pembuatan kompos dan cara aplikasinya menjadi tolak ukur keberhasilan/hasil kegiatan.

Evaluasi akhir dilakukan untuk melihat sampai sejauh mana materi yang sudah diberikan dapat diaplikasikan dilapangan pada musim tanam yang akan berjalan. Selain melakukan evaluasi pada akhir tahapan proses juga dilakukan monitoring untuk melihat tindak lanjut dan dampak yang ditimbulkan dari kegiatan pengabdian ini, sehingga diharapkan 
program alih teknologi ini dapat tersebar secara luas kepada masyarakay yang lain dan bisa dijadikan alternatif untuk memulihkan kesehatan dan kesuburan lahan sawah secara berkelanjutan.

\section{Target dan Luaran}

Target dan luaran yang akan dicapai dalam kegiatan pengabdian Pelatihan Teknis Pembuatan Kompos Jerami Padi di Desa Banjarrejo Kecataman Batanghari Kabupaten Lampung Timur, antara lain :

a. Anggota kelompok tani yang menjadi mitra kegiatan ini memahami arti penting jerami untuk menjaga kelestarian kesehatan dan kesuburan lahan sawah, ke depan diharapkan $75 \%$ petani tidak lagi membuang dan membakar jerami setelah panen.

b. Petani mempunyai keterampilan untuk melakukan pengomposan jerami secara mandiri dan mampu mengaplikasikan ke lahan sawah secara benar. Ditargetkan $50 \%$ petani dapat melakukan hal ini sehingga kondisi lahan sawah yang diusahakannya lambat laun akan semakin sehat dan subur.

c. Target selanjutnya adalah adanya peningkatan produktivitas padi pada lahan sawah yang mengadopsi teknologi penggunaan kompos jerami sebesar 10$15 \%$ dibandingkan dengan lahan yang masih dikelola secara konvensional.

\section{HASIL DAN PEMBAHASAN}

Upaya untuk meningkatkan pengetahuan dan pemahaman petani (anggota kelompok tani) tentang manfaat jerami dalam kegiatan Pengabdian Kepada Masyarakat (PKM) Desa Banjarrejo Kecamatan Batanghari Kabupaten Lampung Timur, dilakukan dengan memberikan penyuluhan. Materi yang disampaikan berisi tentang manfaat jerami terhadap peningkatan kesuburan lahan sawah, kebiasaan-kebiasaan buruk yang sering dilakukan petani terhadap jerami, potensi kandungan hara yang terdapat pada jerami, dan cara membuatnya menjadi kompos.

Acara yang dikemas secara santai tetapi tetap serius ini juga diselingi dengan tanya jawab seputar materi yang disajikan dan curah pendapat tentang kebiasaan anggota Kelompok Tani Eko Budi dalam mengelola jerami padi selama ini. Dari hasil diskusi dan curah pendapat banyak diketahui bahwa prilaku abai dan kurang peduli yang sering dilakukan petani dalam menangani jerami selama ini akibat ketidakpahaman dan terbatasnya pengetahuan seputar manfaat jerami. Jerami ternyata dapat dipergunakan untuk meningkatkan kesehatan lahan sawah.

Setelah acara penyuluhan dan diskusi seputar manfaat jerami selesai dilaksanakan, kegiatan dilanjutkan dengan pelatihan teknis pembuatan kompos jerami. Pada tahap awal dilakukan pengenalan terhadap bahan-bahan yang diperlukan seperti jerami, decomposer, plastik penutup, dan pipa kontrol. Selanjutnya dilakukan praktik pembuatan kompos jerami, diawali dengan menyusun jerami dalam tumpukan setinggi $+/-20 \mathrm{~cm}$ secara bertahap hingga ketinggian $100 \mathrm{~cm}$. Pada setiap tahap tumpukan jerami dilakukan penyiraman dengan air dan larutan decomposer secara merata. Kandungan air pada tumpukan jerami diusahakan memenuhi kapasitas lapang. Terakhir tumpukan jerami ditutup dengan plastik untuk menjaga kelembaban dan mempercepat proses dekomposisi.

Hasil monitoring setelah 14 hari sejak pengomposan terlihat bahwa volume tumpukan jerami menyusut 30-40\%, suhu yang pada tahap awal relative tinggi berkisar antar $60-70{ }^{\circ} \mathrm{C}$ sudah menurun berkisar 35 $40{ }^{\circ} \mathrm{C}$. Tekstur jerami melunak dan berwarna coklat kehitaman. Pada bagian tumpukan jerami juga terlihat jelas 
munculnya hifa dan jamur berwarna putih yang menandakan proses dekomposisi jerami berjalan dengan baik.

Kompos jerami yang sudah jadi dapat diaplikasikan ke lahan sawah. Aplikasi dapat dilakukan bersamaan dengan pengolahan tanah atau dapat juga diaplikasikan pada waktu setelah penyiangan pertama (sekitar umur 3 minggu setelah tanam). Didorong oleh rasa keingintahuan yang begitu tinggi dan tekad kuat untuk memperbaiki kesalahan di masa lalu, membuat petani begitu antusias mengikuti tahap demi tahap pada praktik pembuatan kompos jerami.

\section{Peningkatan Kesuburan Lahan}

Penggunaan kompos jerami terbukti dapat meningkatkan kandungan unsur hara dan kandungan bahan organic tanah sawah. Hal ini dapat diketahui dari hasil analisis tanah pada lahan sebelum dan sesudah aplikasi seperti ditampilkan pada Tabel 2.
Dengan adanya perbaikan tingkat kesuburan lahan, pertumbuhan tanaman padi yang dibudidayakan juga akan semakin baik dan yang tidak kalah penting adalah kelestarian kesehatan lahan sawah akan terjaga secara berkelanjutan.

\section{KESIMPULAN}

1. Jerami padi sangat bermanfaat untuk dipergunakan sebagai sumber bahan organik untuk menjaga dan meningkatkan kesehatan lahan sawah secara berkelanjutan.

2. Kegiatan PKM tentang Pelatihan Teknis pembuatan kompos dari bahan baku jerami padi, mampu meningkatkan keterampilan kepada anggota Kelompok Tani Eko Budi Desa Banjarrejo Kecamatan Batanghari Kabupaten Lampung Timur dalam memanfaatkan jerami untuk menjaga dan meningkatkan kesuburan lahan sawah.

Tabel 2 Indikator keseburan tanah sebelum dan sesudah aplikasi kompos jerami

\begin{tabular}{clccc}
\hline \multirow{2}{*}{ No } & \multirow{2}{*}{ Parameter Uji } & \multicolumn{2}{c}{ Aplikasi kompos } & \multirow{2}{*}{ Satuan } \\
\cline { 3 - 4 } & & Sebelum & Sesudah & \\
\hline 2 & $\mathrm{pH}$ & $\mathrm{N}-\mathrm{42}$ & 4,76 & $\%$ \\
\hline 3 & $\mathrm{P}-$ Tersedia & 0,162 & 0,558 & $\mathrm{ppm}$ \\
\hline 4 & $\mathrm{~K}-\mathrm{dd}$ & 6,094 & 7,085 & $\mathrm{me} / 100 \mathrm{~g}$ tanah \\
\hline 5 & $\mathrm{Na}-\mathrm{dd}$ & 0,263 & 0,125 & $\mathrm{me} / 100 \mathrm{~g}$ tanah \\
\hline 6 & $\mathrm{Ca}-\mathrm{dd}$ & 0,313 & 0,188 & $\mathrm{me} / 100 \mathrm{~g}$ tanah \\
\hline 7 & $\mathrm{Al}-\mathrm{dd}$ & 1,529 & 2,015 & $\%$ \\
\hline 8 & $\mathrm{C}-$ Organik & 0,742 & 0,585 & $\%$ \\
\hline 9 & KTK & 0,892 & 1,471 & $\mathrm{me} / 100 \mathrm{~g}$ tanah \\
\hline
\end{tabular}

Sumber : Laboratorium Analisis Politeknik Negeri Lampung 2013

Dari hasil analisis tanah tersebut diketahui bahwa terjadi peningkatan kandungan hara dan bahan organic pada tanah sawah setelah dilakukan aplikasi menggunakan kompos jerami. Peningkatan cukup signifikan terjadi pada kadar bahan organic tanah. Kandungan bahan organic tanah merupakan indicator kesehatan lahan.
3. Kompos jerami padi dapat meningkatkan kandungan hara tanah dan bahan organik lahan sawah secara berangsur.

4. Penggunaan kompos jerami pada budidaya padi sawah secara berkelanjutan dapat meningkatkan produksi padi. 
UCAPAN TERIMAKASIH

Politeknik Negeri Lampung yang telah mendanai kegiatan ini melalui skema BOPTN T.A. 2013.

\section{DAFTAR PUSTAKA}

Dulbari. 2012. Uji Daya Hasil Beberapa Genotipe Padi Sawah (Oryza sativa L.) pada Dua Lokasi Berbeda. Tesis Pascasarjana Magister Agronomi Fakultas Pertanian Universitas Lampung.

Harjowigeno. 1995. Ilmu Tanah. Edisi Revisi. Penerbit Akademika Pressindo. Jakarta. 126 hlm.

Monografi . 2010. Monografi Desa Banjarrejo Kecamatan Batanghari. Bagian Tata Pemerintahan Kabupaten Lampung Timur. $32 \mathrm{hlm}$.

Rauf, A. 2007. Wacana Medan Bisnis. Terbit Senin 22 Januari 2007. hlm 10.

Simarmata, T. 2008. Teknologi Intensifikasi Padi Aerob Terkendali Berbasis Organik (IPAT-BO) Untuk Melipatgandakan Produksi Padi, Mempercepat Kemandirian Dan Ketahanan Pangan Di Indonesia. Makalah pada Pengukuhan Guru Besar Pada Tanggal 2 Mei 2008.

Simarmata, T. dan Joy, B. 2011. Teknologi Pemulihan Kesehatan Lahan Sawah dan Peningkatan Produktivitas Padi Berbasis Kompos Jerami dan Pupuk Hayati (Biodekomposer) secara Berkelanjutan di Indonesia. Makalah Seminar Teknologi Pemulihan Kesehatan Lahan Sawah dan Peningkatan Produktivitas Padi pada Tanggal 4 Februari 2011 di Politeknik Negeri Lampung.

Turmuktini, T. dan Simarmata, T. 2010 . Peranan Kelimpahan Mikroba Tanah dalam Sistem Budidaya Intensifikasi Padi Aerob Terkendali Berbasis

\begin{tabular}{llr} 
Organik & (IPAT-BIO) & untuk \\
Meningkatkan & \multicolumn{2}{c}{ Pertumbuhan dan } \\
Produktivitas & Padi di & Indonesia. \\
Proseding & Seminar & Nasional \\
Biodiversitas & III. Jurusan & Biologi \\
Fakultas Sain dan Teknologi. UNAIR. & UNA \\
\multicolumn{2}{l}{ Surabaya 31 Juli 2010. hlm 1-9. }
\end{tabular}

Surabaya 31 Juli 2010. hlm 1-9. 